\title{
EFFECT OF DILATATION OF THE CEREBRAL VENTRICLES AFTER THE ADMINISTRATION OF NITROXYNIL IN SWISS ALBINE MICE DURING ORGANOGENESIS
}

\author{
Gustavo Rodrigues Queiroz', Luiz Fernando Coelho da Cunha Filho², Aline \\ Tramontini Zanluchi², Flávio Antonio Barca Junior², Werner Okano² \\ 1 UEL \\ 2 UNOPAR \\ Correspondência: Luiz Fernando Coelho da Cunha Filho: luiz.cunha@unopar.br
}

\begin{abstract}
Nitroxynil $34 \%$ is an anthelmintic of the family of phenolic substitutes that is used for treatment and control of Fasciola hepatica, but is very effective in controlling haemoncosis in sheep. The objective of this study was to evaluate the effects of nitroxynil administered to female Swiss albine mice during the period of organogenesis. A total of 40 mice (30 females and 10 males), randomized into three mated female groups were used: Gc, control animals that were not exposed to nitroxynil; G10, animals that received nitroxynil at the dosage of $10 \mathrm{mg} / \mathrm{kg}$; and G40, where $40 \mathrm{mg} /$ $\mathrm{kg}$ of nitroxynil was administered. All animals received the pre-determined dosage of nitroxynil $34 \%$, via subcutaneous, on the 6th day of pregnancy, and were euthanized on day 21 of gestation. The fetuses and uterus were evaluated for gross abnormalities. The results have demonstrated that the administration of nitroxynil had no influence on the reproductive indices, post-implantation losses, and the number of implantation sites. However, histopathological evaluation of fetal brain revealed an increased in the occurrence of ventricular dilatation. These results suggest that the subcutaneous administration of nitroxynil $34 \%$ at the doses of 10 and $40 \mathrm{mg} / \mathrm{kg}$, in a single application, on the 6th day of pregnancy in female mice, resulted in alterations on the brain of mice and on the birth weight of the fetus.
\end{abstract}

Key Words: anthelminthic drug; embryonic toxicity; phenolic substitutes; laboratory animals

\section{EFEITO DE DILATAÇÃO DOS VENTRÍCULOS CEREBRAIS APÓS A ADMINISTRAÇÃO DE NITROXINIL EM CAMUNDONGOS SWISS DURANTE A ORGANOGÊNESE}

RESUMO: O nitroxinil 34\% é um anti-helmíntico da família dos substitutos fenólicos utilizado no controle das Fasciola hepática, mas é muito eficaz no controle das hemoncoses em ovinos. O objetivo deste trabalho foi avaliar o efeito do nitroxinil administrado em camundongos fêmeas Swiss albine durante o período da organogênese. Foram utilizados 40 camundongos (30 fêmeas e 10 machos), acasalados e randomizados em três grupos de fêmeas: grupo controle (Gc), grupo nitroxinil $10 \mathrm{mg} / \mathrm{kg}$ e $40 \mathrm{mg} / \mathrm{kg}$, grupos $\mathrm{G}_{10}$ e $\mathrm{G}_{40}$, respectivamente. No $6^{\circ}$ dia de prenhez, estes animais

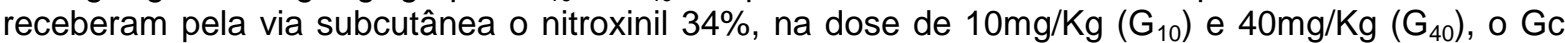
recebeu solução fisiológica pela mesma via. Os animais foram submetidos à eutanásia no $21^{\circ}$ dia de gestação, sendo avaliados os fetos e os úteros. Os resultados revelaram que não ocorreu influência do tratamento e da concentração nos índices reprodutivos, fundamentada nas perdas pósimplantação e nos números de sítios de implantação. Entretanto, na avaliação dos fetos o exame histopatológico do encéfalo revelou aumento da ocorrência de dilatação ventricular. Conclui-se que o nitroxinil $34 \%$ nas dosagens de 10 e $40 \mathrm{mg} / \mathrm{Kg}$, quando administrado por via subcutânea em aplicação única no $6^{\circ}$ dia de prenhez em camundongos fêmeas, demonstrou causar alterações no cérebro e no peso ao nascimento dos fetos de camundongos.

Palavras-chave: vermífugo; embriotoxicidade; substitutos fenólicos; animais de laboratório 
Swiss albine mice during organogenesis

\section{INTRODUCTION}

Nitroxynil (4-Hydroxy-3-lodo-5NitrobenOnitrile) is a potent antihelminthic from the family of substituted phenols that is utilized in ruminants for the control of trematodes, particularly for Fasciola hepatica. However, this antihelminthic has been widely utilized in the control of Haemonchus contortus (haemonchois) in sheep due to its effectiveness (McKeller and Kinabo, 1991). Probably, because this drug is strongly linked to plasmatic proteins, thereby promoting adequate tissue distribution and due to its slow elimination can be observed with the plasma of sheep as much as 48 days after a subcutaneous administration (Almeida and Ayres, 2011).

The increasing use of phenolic substitutes in the control of hemoncosis, particularily in cases of anthelmintic resistance to other drugs (Cunha Filho, 1999; Reinemeyer and Courtney, 2003), associated with increased susceptibility of females in late pregnancy and lactation to parasitic infestation (Amarante, 1990), and since nitroxynil passes the placental barrier reaching the fetus (Bernardi, 2006), justify the concern of the occurrence of elevated incidences of teratogenic effects. However, there are few studies that evaluated the teratogenic effect of nitroxynil. Sobbhy (1997) evaluated the teratogenic effects of Nitroxynil applied to pregnant rats during organogenesis and related that the experimental groups that received subcutaneous infusions of $5 \mathrm{mg}$ nitroxynil showed signs of teratogenicity in their offspring, including dilatation of cerebral ventricles. Consequently, the objective of this study was to evaluate the teratogenic effects of nitroxynil administered to Swiss albine mice during organogenesis, since the drug has caused alterations in the brain of fetus of other species (Sobbhy, 1997).

\section{MATERIAL AND METHODS}

\section{Animals}

Thirty, 50 and 60 days of age, female, non-pregnant, Swiss albine mice, and 10 male mice were used during this experiment. The animals received commercially prepared ration with water ad libitum, and were maintained in a bright and darkened circular environments during 12 hours at the animal facilities of the Universidade Norte do Paraná.

\section{Mating strategy}

The mice were allowed to mate at the beginning of the experiment at the proportion of $3: 1$ (females: males; Harkness and Wagner, 1993) for a period of 12 hours (dark cycle). The confirmation of copulation was determined 12 hours after the beginning of mating due to the presence of sperm observed by a vaginal smear, and was considered as the first day of pregnancy (Romero et al., 1992).

\section{Experimental design}

The females were randomly divided into three groups ( $n=10): \mathrm{Gc}$, consisted of the control animals that were not exposed to nitroxynil but received saline solution; $\mathrm{G}_{10}$, made up of animals that received nitroxynil $34 \%$ at $10 \mathrm{mg} / \mathrm{kg}$ body weight (BW); and $\mathrm{G}_{40}$, mice that received nitroxynil $34 \%$ at $40 \mathrm{mg} / \mathrm{kg} \mathrm{BW}$. These dosage of nitroxynil were choose according to McKellar and Kinabo (1991), being the $10 \mathrm{mg} / \mathrm{kg}$ the therapeutic dosing and $40 \mathrm{mg} / \mathrm{kg}$ the higher dose before toxicity occurs. $G_{10}$ and $\mathrm{G}_{40}$ animals received a single dose of nitroxynil administered via subcutaneous, on the sixth day (beginning of organogenesis) of pregnancy. The females, from each group, were maintained in cages until the end of the experiment. 


\section{Euthanasia}

On day 21 of pregnancy, all females were euthanatized with sodium thiopental $(35 \mathrm{mg} / \mathrm{kg}$, intraperitoneally), after which the abdominal cavity was surgically incised, the gravid uterus was exteriorized and dissected. The gravid uterus and ovaries were then separated for gross evaluation of possible uterine and fetal abnormalities, after which the number of reabsorption sites and implants within the uterine wall was determined. Additional gross evaluation of foetuses consisted of determination of possible anatomical malformation, weight variations, and fetal vitality.

\section{Post-implantation loss}

The post-implantation losses were determined based on the method described (Lemonica et al., 1995; Möller et al., 2003) by using the following formula: post-implantation loss= [(number of implantation sites - number of foetuses) $\times 100 \div$ number of implantation sites].

\section{Histopathological evaluation}

The tissues fragments of the brain of all foetuses were fixed by immersion in $10 \%$ buffered formalin solution. Portions of the cephalic segments were dissected as follows: palate surface down, 3 coronal sections made immediately frontal to the eyes, through the eyes and retro-occulary passing the lateral ventricles (Wilson, 1979), all the section were utilized in this study. Histological preparations from the cortex and lateral ventricles off the offspring were prepared by inclusion in paraffin and sliced in 6 micrometer thickness, and dyeing with hematoxilin and eosin (HE) preparation. The fragments of all foetuses were evaluated, under light optical microscopy (objective 20x) and were compared with the control group.

\section{Statistical analyses}

Quantitative variables with normal distribution were expressed as mean and standard deviation, comparisons were performed using analysis of variance and between groups using the t-test for independent samples. For qualitative variables was used the frequencies and percentages for data presentation and the chi-square test for comparisons. In all cases, it was considered a minimum significance level of $5 \%$.

\section{RESULTS}

The administration of nitroxynil at doses of 10 and $40 \mathrm{mg} / \mathrm{kg}$ at the $6^{\text {th }}$ day of pregnancy did not affect the vitality of the fetuses. No gross external alterations were observed in the groups of fetuses evaluated (Table 1). By histopathology, groups $\mathrm{G}_{10}$ and $\mathrm{G}_{40}$ animals showed a significant increase in dilatation of cerebral ventricles relative to the control group, but significant differences were not observed between the treated groups (Table 1). Significant differences in the fetal body mass were observed between the groups Gc, G10 and G40. However, no significant difference in the male:female ratio and body mass per litter was observed. The reproductive rates of female mice treated with nitroxynil are given in Table 2; however, no significant difference was observed in the parameters evaluated.



Similar letters in the same line indicate values of no statis tically difference, different letters within the same line indicate statis tically different values $(p<0,05$.

Table 2 - Mean values and standard deviation of the averages of the reproductive indexes of female mice treated with $34 \%$ nitroxynil

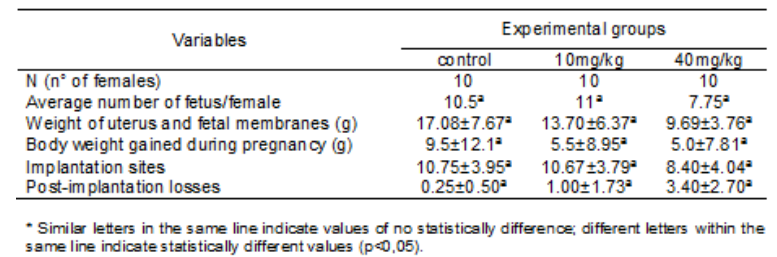

Similar letters in the same line indicate values of no $s$
same line indicate statistically different values $(p<0,05)$. 
Effect of dilatation of the cerebral ventricles after the administration of nitroxynil in

Swiss albine mice during organogenesis

\section{DISCUSSION}

The results from this study have demonstrated that nitroxynil 34\% administered subcutaneous route on the $6^{\text {th }}$ day of pregnancy, at doses of $10 \mathrm{mg} / \mathrm{kg}$ and $40 \mathrm{mg} / \mathrm{kg}$, although it had not cause any external malformation, it, apparently caused an increase in the incidence of dilatation of cerebral ventricles in fetal Swiss albine mice. Similar results were described by Sobbhy (1997), who observed dilatation of cerebral ventricles when nitroxinil was administered to pregnant rats during organogenesis. Marchi et al. (2001) found similar observations in the lateral ventricles of fetus of rats that received lamotrigine, drug that, similar to nitroxynil, has teratogenic effects. The increase of the ventricles could be explained by stenosis of the aqueduct of Sylvius, narrow structure that allows communication between the third and fourth ventricle, resulting in hydrocephalus can be genetic in origin (X-linked), by infection, teratogenic or neoplastic origin. Characterized by dilatation of the lateral ventricle and III ventricule (Malagon-Valdez, 2006).The dilated ventricles observed in this study might be expression of the toxicity of the product acting as an inhibitor of mitochondrial oxidative phosphorylation, probably interfering with the functioning of the mechanisms of ionic pumps of the cell membrane (Guyton and Hall, 1997). The eyes, brain, heart, axial skeleton, palate, and the urogenital system are the organs that are most susceptible during the early period $\left(6^{\text {th }}-18^{\text {th }}\right.$ day) of organogenesis in mice (Schüler et al., 1998). This study evaluated only cerebral alterations.

This study demonstrated a decrease in fetal body weight of $G_{10}$ animals relative to that of the controls group. Contradictory results were described by Sobbhy (1997), in which an increase in the body weight of fetuses was observed in animals that received 5 and $10 \mathrm{mg} / \mathrm{kg}$ of nitroxynil. Marchi et al. (2001) observed low birth weight of rats fetus when were administered lamotrigine on days 9,10 and 11 of pregnancy. In this study, there were no difference in the average of number of fetus/female between all groups, additionally, $100 \%$ of fetal reabsorption and a significant decrease of implantation sites at the dose of $10 \mathrm{mg} / \mathrm{kg}$ were also previously described (Sobbhy 1997). These alterations were not observed during this study. The differences in the results of body mass and fetal reabsorption observed between our study and that of might be associated with the time of application of nitroxynil; being applied on day 6 in this study and on day 15 in the experiment done by Sobbhy (1997).

In this study, the drug was used beyond the recommendation dosage, i.e., $10 \mathrm{mg} / \mathrm{kg}$, as a single dose at the beginning of organogenesis. However, due to the long residual effects of nitroxynil where plasma residues have being found in sheep and cattle up to 30 days after application (Almeida and Ayres, 2011), the elimination of the drug would probably happen as repeated doses at short interval.

Organogenesis or embryogenesis is the period during which tissue differentiation occurs and consequently the formation of rudimentary organs (Schüler et al., 1998); Therefore, if drugs are administered to pregnant females during this period, teratogenesis might occur if the lesion is compatible with the life of the fetus or embryo lethality if the injury is not compatible (Bernardi, 2006). This might suggest that a teratogenic agent does not produce a determine malformation, but increases the frequency by which anomalies occur, as was observed during this experiment (Bernardi, 2006). 
Phenolic substitutes, such as nitroxynil and niclofolan are well known anthelmintic drugs, which are used to control infections induced by trematodes, cestodes and nematodes, but have elevated levels of toxicity (Spinosa et al, 2011).

Teratogenic effects were observed with the use of niclofolan in cattle (Almeida and Ayres, 2011), nevertheless nitroxynil has been recommended for use in pregnant females without the risk of teratogenic effects (Almeida and Ayres, 2011), being well tolerated at therapeutic dosage of $10 \mathrm{mg} / \mathrm{kg}$, while higher doses are not recommended due to potential adverse reactions (Reinemeyer and Courtney, 2003).

\section{CONCLUSION}

Results from this study have demonstrated that nitroxynil 34\% administered at doses of 10 and $40 \mathrm{mg} / \mathrm{kg}$, subcutaneously, in a single application, on the 6th day of pregnancy in female mice, produces alterations on the brain of mice and on the birth weight of the fetus. Further research must be carried out to corroborate these findings and establish their application in others species.

\section{INFORMATIVE NOTES}

Usage of animals during this study was authorized by the Ethics Committee for the Experimental Usage of Animals (CEA/UNOPAR n007/11).

\section{REFERENCES}

ALMEIDA, M.A.O.; AYRES, M.C.C. Agentes anticestódeos e antitrematódeos. In: SPINOSA, H.S.; GÓNIAK, S.L.; BERNARDI, M.M.

Farmacologia Aplicada a Medicina

Veterinária, $5^{\mathrm{a}}$ ed. Rio de Janeiro: Guanabara Koogan, 2011. cap.44, p.510-516.

AMARANTE, A.F.T. Profilaxia da verminose ovina, descontaminação de pastagens. In:
SILVA SOBRINHO, A.G. (Ed.). Produção de Ovinos, Jaboticabal: FUNEP, 1990. cap.18, p.201-210.

BERNARDI, M.M. Exposição aos Medicamentos Durante o Período Perinatal. In: SPINOSA, H.S.; GORNIAK, S.L.; BERNARDI, M.M.

Farmacologia Aplicada a Medicina

Veterinária, $4^{a}$ ed. Rio de Janeiro: Guanabara Koogan, 2006. cap.63. p.807-816.

CUNHA FILHO, L.F.C. Quimioresistência aos anti-helmínticos em ovinos. Unopar Científica Ciências Biológicas e da Saúde, v.1, n.1, p.91102, 1999.

\section{GUYTON, A.C.; HALL, J.E. Tratado de}

Fisiologia Médica, $9^{a}$ ed., Rio de Janeiro: Guanabara Koogan, 1997. p.285-286.

HARKNESS, J.E.; WAGNER, J.E. Biologia e Clínica de Coelhos e Roedores, $3^{\mathrm{a}}$ ed. São Paulo: Roca, 1993, p.41-47.

LEMONICA, I.P.; DAMASCENO, D.C.; STASI, L.C. Study of the embryotoxic effects of an extract of rosemary (Rosmarinus officinalis L.).

Brasilian Journal of Veterinary Research and Animal Science, v.29, p.223-227, 1995.

MALAGÓN-VÁLDEZ; J. Hidrocefalia congénita. Rev Neurol, v. 42 (Supl 3), p.39-44, 2006. MARCHI, N.S.A.; AZOUBEL, R., TOGNOLA, W.A. Teratogenic effects of lamotrigine on rat fetal brain. Arq. Neuropsiquiatr, v.59, n.2, p.362-364, 2001.

MCKELLAR, A.Q.; KINABO, L.D.B. The Pharmacology Of Flukicidal Drugs. British Veterinary Journal, v.147, p.306-321, 1991.

MÖLLER, V.M.; DALLEGRAVE, E.; COELHO, R.; PEREIRA, et al. Efeitos da Ivermectina (Ivonec $\AA$ 1\% injetável) administrada a ratas Wistar durante o período de organogênese. Brazilian Journal of Veterinary Research and Animal Science, v.40, p.328-333, 2003.

REINEMEYER, C.R.; COURTNEY, C.H. Fármacos Anticestóides e antitrematóides. In: ADAMS, H.R. Farmacologia e terapêutica em veterinária, $8^{\mathrm{a}}$ ed. Rio de Janeiro: Guanabara Koogan, 2003. cap.48, p.819-828.

ROMERO, A.; VILLAMAYOR, F.; GRAU, M.T.; et al. Relationship between fetal weight and litter size in rats: Application to reproductive toxicology studies. Reproductive Toxicology, v.6, p.453-456, 1992. 
SCHÜLER, L.; SANSEVERINO, M.T.V.;

SOUZA, C.F.M.; et al. Fármacos e gestação. In:

FUNCHS, F.D.; WANNMACHER, L.

Farmacologia Clínica -fundamentos da

terapêutica racional, $2^{\mathrm{a}}$ ed. Rio de Janeiro:

Guanabara Koogan, 1998. cap. 62. p.602-608.

SOBBHY, H.M. Effect of the anthelmintic (nitroxinil) on fetal development, sexual organs weight and epididymal sperm characters in rats. Egyptian Journal of Comparative Pathology and Clinical Pathology, v.10, n.1, p.64-73, 1997.

SPINOSA, H.S.; GÓNIAK, S.L.; BERNARDI, M.M. Farmacologia Aplicada a Medicina Veterinária, $5^{\mathrm{a}}$ ed. Rio de Janeiro: Guanabara Koogan, 2011.p.895.

WILSON, J.G.; Current status of teratology. In: WILSON, J.G.; FRASER, F.C. The handbook of teratology, $2^{\text {nd }} E d$. New York: Plenum Press. 1979, p.47-74. 